\title{
Remembering the Present: Dealing with the Memories of Terrorism in Europe
}

\section{by Ana Milošević}

\section{(cc) $\mathrm{EY}$}

This work is licensed under a Creative Commons Attribution 3.0 License.

\begin{abstract}
Whilst the interest of memory scholars in political violence and more specifically in terrorism is not novel, there appears to be a certain urgency to reflect upon memories of terrorist violence in collective, European immaginarium. By questioning how to deal with these memories and how the process of remembrance of the victims of terrorism will pave its way into a European memory culture, this article analyses spontaneous memorialization of the victims of terrorist attacks in Brussels (2016).

W hilst the interest of memory scholars in regards to political violence and more specifically, terrorism, is not novel, immediately following the terrorist attacks in Paris (2015) and Brussels (2016) there appears to be a certain urgency to reflect upon these nascent memories in collective, European immaginarium. This article traces the development of a "bottom-up" memorialization process in the immediate aftermath of terrorist attacks in Brussels (March-July 2016), questioning how these acts of terrorisms will settle in our collective memory. By scrutinizing unprompted memorialization of the Brussels' attack victims, I analyse social meanings and roles assigned to the spontaneous memorialization emerging in hours and days after these traumatic events. The implicated research is based on data collected through the techniques of ethnographic observations, explorative interviews with the visitors and documentary analysis of memorabilia in three spontaneous memorials' sites (Place de la Bourse, Maelbeek and Zaventem airport). Arguing that spontaneous memorialization is more than a simple vehicle for coming to terms with a trauma and a pre-step of "official" memory works, this article draws attention to the challenge before policy makers of transforming these ephemeral places of memory into an "official" monument without disfiguring the meanings to it attached by their own makers.
\end{abstract}

Keywords: collective memory; Brussels attacks; terrorism; spontaneous memorials; memorialization; European memory;

\section{Introduction}

The morning of 22 March 2016, two separate terrorist attacks occurred in Belgium, one at the Airport in Zaventem and the other at Maelbeek metro station in Brussels [1]. Plunging the city into a day-long lockdown, many of the Brussels' residents disobeyed the Government's calls to stay at home: in a symbol of defiance and solidarity, assembling spontaneously at the Place de la Bourse (The Bourse) to pay tribute to the victims of the attacks. The Bourse, Brussels' stock-exchange plaza, was transformed into a spontaneous memorial-a giant blackboard where people with chalk draw images and wrote messages of peace, solidarity but also of anger. As in the Place de la Republique after the Paris attacks [2] (2015), the emergence of spontaneous memorials became a vehicle for dealing with trauma, deliberation of emotions and narratives of 
what was a societal response to a tragedy.

Collective trauma whether of natural (e.g. earthquake, hurricane) or human-made causes (e.g. terrorism, plane-crash) has the capacity to affect an entire community. "At times, a collective traumatic event is so overpowering, so shattering, that it tests that stock of knowledge and if that cultural system can offer no real explanation for the event or its aftermath, the members of the culture are left epistemically disempowered, that is, they are at a loss to explain what happened and why, and to derive any meaning from their own suffering" (De Young 1998). Yet, "differently from the past traumatic experiences often perceived as natural and inevitable, the nature of the violence and trauma has changed recently, making it possible for a collective response to trauma" (Moodley and Costa 2006, 40). The death of celebrities such as Lady Diana (1997), Chernobyl nuclear disaster memories (1986) or numerous mass-shootings in the American high-schools illustrate that the grief, "the intensely painful experience that results when a meaningful loss has occurred" (Granek 2014, 61), seems to transcend the individual's realm of expression as "collective traumas [can] negatively affect large numbers of people who ostensibly did not experience traumatic events directly" (Seery et al. 2008, 657).

After the events in Madrid [3] (2004), London [4] (2005), Utøya (2011) [5] and especially the attack on satiric journal Charlie Hebdo in Paris (2015), the question of how to deal with the memory of terrorism and its victims is steadily gaining momentum throughout the whole of Europe. In the days and months after the most recent attacks in the aforementioned European capitals, the pressing issue in politics and society seems to be a reflection of: the nature of terrorism itself, the destiny of the victims and their families, prevention of further attacks and motivation behind "a home-grown terrorism" (Tota 2005). As Tota (2005, 56-57) argues: "In the short-term perspective, both politically and scientifically speaking, immediately after a terror attack the most important thing is to find out by all possible means how to prevent further attacks and prosecute the terrorists." Nevertheless, wider social consequences of these collective traumas must not be underestimated: How will these acts of terrorisms settle in our collective memory? Shall the victims be memorialized by the official memory entrepreneurs or they shall continue to "live on in hearts but not in stone?"

Spontaneous memorials emerging in an immediate aftermath of a terrorist attack (e.g. Place de la Republique, Paris; Place de la Bourse, Brussels) seem to increasingly appeal not only to the local community but also to the other groups and communities who did not directly suffered a trauma or a human loss. In addition, if we observe the most recent acts of terror, such as the Nice attack [6] (2016) or Orlando shootings [7] (2016), emergence of a spontaneous memorial after a collective trauma does not appear anymore to be an exception but an unwritten rule. What role do different memory actors (e.g. citizens, victims' families, governmental officials) ascribe to these spontaneous memorials? Can we consider this "bottom-up" memorialization to be a societal answer to a trauma or a collective expression of grief that makes use of memorialising language (e.g. "never forget", "remember", "forever in our hearts")?

Not much is known regarding the process of spontaneous or unprompted memorialization that precede "official" memory works such as: establishment of remembrance days, creation of a memorial or a monument. In addition, the vast literature on memorialisation offers limited answers in terms of memorials remembering the victims of terrorism - a relatively a new form of public monument which still have not gained significant scholarly attention (see e.g. Moodley and Costa 2006, Savage 2009, Donofrio 2010). In terms of existing cases, there have been few attempts of studying memorialization process involving the victims of terrorism in European context, with an exception of the Northern Ireland, Spain and Italy (see e.g. Tota 2004, 2005, 2013; Margry and Sànchez-Carretero 2007, 2011). There is a need for a better understanding 


\section{Journal of Terrorism Research}

of how society copes with the trauma of terrorism through memorialization, especially in the immediate aftermath of the event when narratives and meanings of the traumatic event are being rehearsed and negotiated (see e.g. Simpson and Corbridge 2006).

This article seeks to foster-as well as contribute-to the empirical exploration of "spontaneous" memorials (Santino 2006), specifically addressing their potential to represent as mnemonic loci which could play an important role for setting the tone for how traumatic events will enter the collective memory. To this end, the article limits its range of the "knowable" to the early memorialisation process emerging in hours, days and months after the traumatic event. I cautiously refer to this time-frame as "pre-memorial"-defined by Simpson and Corbridge $(2006,566)$ as "the period before an official memorial is erected when the gap between the signified [traumatic event] and the signifier (the memorial) is still wide open and meanings and narratives of the disaster are being created, rehearsed, and contested." As argued in this paper "bottomup" memorialization-unofficial and unprompted memory work occurring in an immediate aftermath of a traumatic event is likely the beginning of the overall memorialization process rather than a pre-stage of "official" memory works which might sub-enter later.

The article unfolds as follows: first, I discuss the nexus between memorialization theory and terrorism studies. In this section, I shed more light on the evolution of the process of memorialization analysing the relationship between permanent and spontaneous memorials and their memory actors. Secondly, by drawing evidence from unprompted memorialization of the Brussels attacks (2016), I ascertain the social meanings of spontaneous memorials, analyse mnemonic practices and purposes ascribed to them by various stakeholders. Next, I analyse the contents of spontaneous memorials as well as their life cycle - the period between the emergence and perishing either through transformation or dismantlement. In the closure, I discuss my findings in a light of a broader literature on memorialization.

\section{Dealing with the memories of terrorism: Between "official" and vernacular, permanent and ephemeral}

Studies addressing traumatic grief and memorialisation after a terrorist attack, while increasing, are small in number (e.g. Alexander et al. 2004, Tota 2005). A number of authors have considered how individuals cope with the acts of terrorism, violence and psychiatric symptoms such as the Post-Traumatic Stress Disorder, PTSD (e.g. Hobfoll et al. 2006; Moodley and Costa 2006). Thus far, many psychologists have studied how memory is mobilized to engage individuals and groups in terrorism and political aggression (e.g. Friedland and Merari 1985, Ginges and Atran 2009) while sociologists, historians and political scientists have sought to determine how societies and individuals remember (e.g. Halbwachs 1925, Anderson 1983, Nora 1989, Assman 2008) and deal with massive human rights violations and violence (e.g. Connerton 1989; Misztal 2003; Zerubavel 2004). Extensive research on memorialization and societal dealing with the past, atrocities of the Holocaust, totalitarian regimes, political violence, genocide and mass-murder (e.g. Arendt 1951; Levi 1958; Jaspers 1961; Bloxham 2005; Connerton 2012) suggests that memory matters both culturally and politically.

As a dynamic process, memorialization is marked by different activities providing the opportunity for people to "celebrate the lives of those who died, to mourn their passing, and to inscribe memories of the deceased in the public consciousness" (Foot et al. 2006, 72). Thus, memorialization can be achieved in many ways, not exclusively using physical memorials such are monuments or museums often created in later stage, but additionally through commemorative rituals, governmental responses and spontaneous memorials preceding "official" memory works. Among these expressions of memory, public sites play an important 


\section{Journal of Terrorism Research}

role in honouring the victims of violence and offering a specific locus for mourning. Pierre Nora's concept of les lieux de mémoire - as places "where [cultural] memory crystallizes and secretes itself” (Nora 1989, 7 ), has been central in last two decades in understanding the purpose of these sites of memory born out of "a will to remember," "to stop time, to block the work of forgetting" (Nora 1989, 19). For Nora $(1989,12)$ lieux de mémoire "originate with the sense that there is no spontaneous memory, that we must deliberately create archives, maintain anniversaries, organize celebrations, pronounce eulogies, and notarize bills because such activities no longer occur naturally." However, as Jay Winter (1995) reminds us "sites of memory" are also" sites of mourning," and as such they reflect the tension between official and vernacular expressions of memory.

The concept of "spontaneous shrines" (Santino 2006) challenge the view of memorialization as a symbiosis of the past and the present, as it considers unprompted mnemonic practices to be more of a contemporary mourning ritual (Santino 2003, 367), located between commemoration and social activism. Born in the present, spontaneous memorials look both in the immediate past and the future, uncontrolled and unconditioned by a previously established narrative of the event. In this sense, improvised memorials could be considered vernacular expressions of memory that has emerged in a response to the present traumatic event. As such, the latter are not an artefact of the time or "official" memory entrepreneurship which might encapsulate certain thinking about the past.

Another characteristic of these spontaneous places of memory is their apparent tendency to emerge promptly after the traumatic event accommodating a wide range of memorial purposes. As this article attempts to enunciate, memorializing helps survivors deal with the sense of loss, fear, uncertainty, helplessness as well as sorrow, and as such encompasses both "a shared memory and an act of collective grieving aiming to restore severed communal bonds and dismantled cultural ideals"(Pivnick 2011, 500). Free of official memory entrepreneurship, these sites of memory are not just vernacular expressions of memory but a pluralistic societal answer to traumatic event. The meanings, emotions and narratives derived from spontaneous memorialization therefore could be crucial in determining how the traumatic event will settle in collective memory.

Certainly, the most well-known example of memorialization of the terrorist victims is the Ground ZeroMemorial to the victims of September 11 (i.e. 9/11). What characterizes the memorialization process of the $9 / 11$ is the often-unchallenged assumption of the decision makers that memorialization offers some kind of closure to participative community. Yet, it is not often that the community is included in the process of designing and construction of memorials, but offered a "creative" solution to come to terms with a tragedy in a form of an "official" monument. In her research on the plans for official memory works at the Ground Zero, Donofrio $(2010,150)$ investigated how an advocacy platform [8] made of family members of the 9/11 victims, attempted "to establish the authority to guide memorial construction by dismissing competing rhetoric as 'political' and employing conservatively charged metaphors of ownership." Her research demonstrates that the Ground Zero became site of "power struggle" between the official and vernacular, the top-down and bottom-up approaches to remembrance. Thus, it might be argued that the shift from spontaneous memorialization to an "official" monument, carries in-and-of-itself a potential danger of misinterpretation and instrumentalization of the meanings attached to places of memory by the "official" memory entrepreneurs or other stakeholders involved in the memorialization process.

Butler (2009) argues that when lives are publicly grieved, the ways in which this grief is conjured up in public discourse is a deeply political issue with tremendous consequences. The example of Ground Zero 


\section{Journal of Terrorism Research}

again, illustrates this point clearly. Granek $(2014,65)$ shows that "the public mourning that followed 9/11 was encouraged and later used by political figures as justification for invasion of Iraq, despite the fact that it was Al Qaida who had taken responsibility for the attacks." For this purpose, the process of memorialization transformed the lives lost into symbols of American patriotism and heroism (Doss 2008). As Granek (2014, 65) stipulates, there is a "tremendous power in the manipulation of grief for political purposes and the ways in which it [is] consciously used in the service of particular political aims."

Comparing emergence of memorials after the Oklahoma and 9/11 with Madrid bombing (2004) and London bombing (2005), Joralemon $(2015,188)$ finds that American memorial projects extend "well beyond the therapeutic management of individual or collective grief." He argues that "the long experience with terrorism in the United Kingdom and Spain has produced a more measured response" to the traumatic event, reflecting in turn in their memorials which are "far simpler and less bureaucratic" (Joralemon 2015, 188). In contrast, American memorials to the victims of terrorism seem to advance "the powerful ideology of American exceptionalism by proclaiming a Phoenix-like rebirth after assaults on the nation's sense of invincibility, whether from traitorous home-grown extremists or foreign religious zealots" Joralemon $(2015,188)$. As such, these memorials are often reflective of nation and state based narratives regarding war and security (Doss 2008) while the narratives of victims [9], victims' families and groups are often obscured by more dominant memorial discourses, namely government and media dominated narratives (Low 2004). This approach to memorialization is highly criticized by the victims' families who are considered important stakeholders, playing a critical role in the transition from spontaneous to a permanent memorial (Britton 2007).

The preservation of the informal character of these memorials is likely dependant from the impact it has on society and the interest it raises. Prior research into the "official" acknowledgement and acceptance of these spontaneous memorials has demonstrated that "the staying power of memorial depends of municipal lenience and on memorial's continued usefulness, the sacrality it generates, and the respect that evokes" (Margry and Sánchez-Carretero 2011, 13). Nevertheless, spontaneous memorials are straddling "between the realms of public and private space "(Margry and Sánchez-Carretero 2011, 13) and as such are not entirely free of agency of public officials, governments and various organizations that deal with the public space (e.g safety, health, maintenance). In addition, spontaneous memorials emerge also in places such are e.g. metro stations, airports, supermarkets which all prior to the traumatic event had a distinct purpose and were managed by both private and state businesses. Therefore, these factors of re-establishment of original or intents purposes could also have an important effect on the temporality of emergent memorials, referred to here as a "life cycle of spontaneous memorial." Bearing in mind the temporality of the spontaneous memorials, this study divides life-cycle of spontaneous memorials into three stages: emergence - marking the birth of the memorial; life - period between the emergence and the first signs of dismantlement of site and finally, perishing - which refers to either an evolution of the memorial or its disappearance.

The primary research methods used for the research included semi-structured interviews with the visitors of memorials, site observation, and visual content analysis of memorabilia at three spontaneous memorials. From the moment of the occurrence of the terrorist act on March, 22. through first two (2) weeks, the main site ( Place de la Bourse) was visited seven (7) times, while the other two sites (Maelbeek metro and the Brussels airport) were visited in four (4) occasions between March and July 2016. Based on field observations (Svendsen and Campbell, 2005), the goal with the site visits was to observe and analyse the life cycle (emergence, life and perishing) of spontaneous memorial while attempting to capture:

- Who are the initiators of the process? What groups, what individuals? 


\section{Journal of Terrorism Research}

- What is the memorial purpose and meaning assigned to these memorials?

- $\quad$ Physical and spatial structure of memorial

- The contents and contexts of memorabilia present in the site

- Eventual shifts in terms of number of visitors, media attention, introduction of scheduled maintenance

- $\quad$ Factors affecting the temporality of memorials

- First signs of introduction of "official memory" works

Exploratory interviews (24) with the mourners were held as a means of investigating the main function of memorials, roles and meanings attached to them by their own makers. Considering that many of the visitors were non-Belgian residents of Brussels, interviews were held not only in French but also in English and Italian language. Interviewees included friends and acquaintances of the victims and (at the certain point of time) the missing, bystanders, community members as well as journalists and street sweepers. In addition, photographs of memorabilia placed on the site were taken, creating a data base which consist of 212 pictures of chalk written messages, post-it papers, images and other objects found in-site (e.g. stuffed toys, candles, flowers, bottles, flags). Photographs were classified by date of the visit to the memorial and the events occurring on that day ( e.g. mass anti-immigrant protest, visit of the Prime Minister).

A visual content analysis of the photographs was undertaken to explore and analyse the imagery and material dimensions of the memorials and memorabilia under this study. Images were coded according to their content: the messages written and/or type of the object portrayed in the picture. The frequency of certain elements in the images was analysed and linked to thematic clusters emerging out of key words, phrases, repeated language, and common ideas (Svendsen and Campbell, 2005). The latter were created to aggregate common codes together into broader themes in order to provide information about the meanings attached to the memorial and memorabilia (Ryan and Bernard, 2003; Svendsen and Campbell, 2005).

\section{Sharing tears and fears: Emergence of spontaneous memorialization after the Brussels attacks}

All over Europe "tears, real and symbolic, ran throughout the day" (Guardian 2016e).

When the first bombs exploded in the departure area of the Zaventem Airport in Brussels, images from the explosions were immediately published on witnesses' social media accounts and taken over by the international media. Pictures of the wounded, dead and terrified passengers running for their lives were broadcasted by almost every TV station in country. While the news of the attacks was seemingly shaking the whole world, an hour later, a third explosion hit a rush hour metro train at Maelbeek station on the Rue de la Loi, which connects city centre with the main European Union institutions. With emergency services rushing to the both parts of the city, Brussels became silent and paralyzed by the shock, with children locked in schools and residents invited to stay where they were until the further notice. A few hours after the tragedy, a small group of citizens, some of them with children, started gathering near the Bourse [10]. In a solemn silence, mourners were praying for the victims and the wounded, lighting candles and crying. By 6 oclock in the afternoon, Belgian Prime Minister Charles Michel and the European Commission's President JeanClaude Juncker visited this emergent spontaneous memorial in the city centre, the plaza was crowded with mourners and covered with messages, flowers and banners. A night-long, candle-lit vigil was taking place 


\section{Journal of Terrorism Research}

while the news of increasing number of wounded and dead founded under debris was whispered among worried mourners.

People from around the world have shown their solidarity with Belgium on social media, as they did previously with Paris, sharing pictures of the famous Belgian Statue Mannequin Pis relieving himself on an assault rifle and of Tintin - Belgium's beloved boy reporter - crying. The iconic Eiffel Tower in addition to other world landmarks such as Burj Khalifa in Dubai, The Brandenburg Gate in Berlin or Rome's Trevi fountain lit up in colours of Belgium: black, yellow and red. In what was emerging as a global wave of commemoration National landmarks were used to express transnational solidarity with Belgium and its victims. This seems to have become an unwritten rule which when not honoured tends to provoke a strong reaction of citizens. For example, in the United Kingdom (UK) media verbally attacked the Mayor for almost no major London monuments took part in the commemorations immediately after the attack. Unlike after the Paris attacks in November 2015, prominent monuments such as Trafalgar Square, the London Eye and Tower Bridge were not lit in different colours immediately after terror attacks in Brussels (Dailymail 2016), rather a few hours later. The terrorist attack in Brussels seem to have provoked not only as Habermas (2012) would say "solidarity among strangers," but also a global wave of grief, resulting in a visible pattern of transnational commemorative practices such is the emergence of spontaneous memorials, erected in honour of victims of the terrorist attacks [11].

In Brussels, three main spontaneous memorials emerged in the following order: Place de la Bourse (The Bourse), Maelbeek metro station and the Zaventem Airport. Initiators of all three memorials range from witnesses and individual survivors and the communities in which they live, to private sector enterprises such are the companies operating in the Zaventem airport or the Brussels' public transportation company, STIB. Among these spontaneous memorials, the Bourse emerges as a central locus of memorialization. The first memorial to emerge was also first in terms of number of visitors, physical surface covered by the memorial and visits of high-profile mourners (e.g. politicians, religious leaders, celebrities).

In the hours immediately following the traumatic event (up until the end of the second week), all three memorials shared a certain number of similarities. As a paramount, emergence of Brussels' spontaneous memorials took place in a "safe environment." Especially in the hours after the attacks, the act of going to the Bourse memorial, itself, became a demonstration of courage and solidarity. While citizens were invited to avoid public gathering because of security concerns, "visiting the memorial was an act of defiance" - explain several interviewed visitors (2016). "I refuse to be taken as a hostage by the fear of terrorists" says a young student from one of the local Universities while humming a song in French (Interview 2016). Despite the appeals to "stay home and stay safe" many of interviewed visitors felt the need to collectively mourn and share they tears and fears of "being blown-up" and "dying without a reason" (Interview 2016). While Place de la Bourse was considered to be the main memorial to which was given significant media attention, other two memorials (where the tragedy actually occurred) emerged the day later [12]. Once that the extraction of the victims and wounded was over in Maelbeek and Zaventem, and the sites proclaimed "safe," mourners started creating memorials by bringing flags, banners, flowers, candles, teddy-bears and other memorabilia.

The second similarity shared by all three memorials is the claim of "authenticity" and closeness to the place of tragedy. While for the Maelbeek metro station and the Airport-as actual sites of death and trauma, the claim of authenticity is direct and linear, Place de la Bourse received a different kind of authenticity validation.

Visits from Belgian politicians amongst them the Prime Minister Charles Michel in the afternoon of the first day of memorials' existence, confirmed its importance-as a place of authentic, living memory. Adding to this 


\section{Journal of Terrorism Research}

validation of authenticity was also the ever-growing media attention for the memorial, with journalist and TV reporters from around the world constantly interviewing and filming the site and its mourners. Strong media presence of journalists and reporters in Brussels contributed to the fast coverage and immediate distribution of images and videos of the attack, while survivors themselves often had the role of real-time reporters sharing their smart-phone's videos and images from crime scenes. Journalists and TV reporters were therefore numerous spectator-visitors who turned these sites of memory into a "media event" (Dayan, 2006). [13]

The violent scenes from the terrorist attacks received world-wide coverage, nevertheless, they were not merely a "media event" but also a manner in which to frame public debate and remember these events, as not only personal or national but also as European issues. Several facts can support this observation. First and the foremost, in the media coverage of the attacks, Brussels is always referred to as "the capital of Europe." Secondly, governmental responses and statements, issued in immediate aftermath of the attack, frame "the event" as "an attack on Europe" and "European values". Few hours after the explosions, French president Francois Holland, as the first European leader to publicly react to the terrorist event, expressed his solidarity with Belgian people saying that Europe was under attack (EU Observer 2016). In an opinion piece in the "Guardian", Italian PM Matteo Renzi writes: "It is true they hit Belgium, but they also hit the capital of Europe," arguing that "terrorists aim to threaten our freedom because they know it is what makes us Europeans" (Renzi 2016). Among the reactions to the attacks by political figures, the image of the EU's foreign policy chief Federica Mogherini crying is certainly one of the most memorable moments. Unable to finish her speech, she told the Jordanian foreign minister, Nasser Judeh: "I will stop here. You will understand this. Today is a difficult day" (Guardian 2016e).

\section{The Bourse memorial: Site of Contestation, Negotiation, and Resistance}

The community of bereavement in these three sites was in time joined by other groups: visitors, bystanders, religious leaders as well as other groups of citizens (e.g. musicians, celebrities) who assigned a broad range of meanings to the memorials. Moreover, many children had been taken to the chalk memorial and candlelight vigil created outside the Place de la Bourse building, offering messages of encouragement, lighting candles alongside adults similarly searching for answers and comfort in the wake of tragedy.

The Bourse was considered also to be a performance stage for both groups and individual expressions of emotive, social and political identity in a public space. As was the case in Brussels and additionally in Place de la Republique after the Paris attacks, different stakeholders (e.g. musicians,) were expressing their own identity and conveying their messages of peace. In both Paris and Brussels, anonymous local musicians performed John Lennon's song "Imagine" engaged the mourners who in one voice sang: "All we are saying is: Give peace a chance." In the Bourse plaza, the Brussels Philharmonic and Vlaams Radio Koor performed Beethoven's "Ode to Joy," "not only [as] the European anthem, but also a call for peace, a hymn of hope for the future" (Vlams Radio Koor, 2016). While the initiative to join the mourners at the Memorial site came directly from the musicians, they had chosen also to perform seeing as "music bonds, helps with healing, with dealing with what has happened, bringing people together" (Vlams Radio Koor, 2016).

However, early politicization of the memorial and abuse of the media attention surrounding the locales occurred starting the first week of the life of the memorial. There were several episodes of Israeli-Palestinian contestations: a hijab-wearing woman was filmed lifting a Palestinian flag while tearing up an Israeli flag to shreds (New York Post 2016); another man was seen picking up a Palestinian flag and placing it over 


\section{Journal of Terrorism Research}

the Israeli flag so it can no longer be seen (Dailymail 2016). In another episode a man stepped into the circle of flags and candles, demanding "justice for Palestine!" Some of gathered mourners protested against his actions, booed the man, shouting for him to "focus on Brussels today" while the others cheered and applauded his statements. Whereas the Bourse was used as a place for Israeli-Palestinian contestations, the Memorial became also a stage for expression of domestic tensions between the national political forces. Domestic political parties, as for example the Flemish, right-wing party Vlaams Belang politicized the terrorist attacks publicly in the media by propagating an anti-Islamic and anti-immigrant measures in response to the attacks. In addition, the party laid a wreath decorated with the Belgian flag and writings "Vlaams Belang" at one of spontaneous memorials. More than an expression of grief for the victims, the wreath itself appeared to be a political statement.

While the memorial was used as a performance stage and a platform by various stakeholders with a political agenda, the most striking moment was the march of anti-immigrant protesters in the first days after the terrorist attack. On 27 March, hundreds of hooligans, some wearing balaclavas and anonymous masks, pushed their way to the Bourse, in an anti-immigrant, islamophobic protest that provoked strong yet peaceful reaction of gathered mourners. Protesters, mainly football supporters, posing as members of "Casuals against terrorism" moved in and occupied the steps of the Bourse - an improvised altar of the memorial. In front of them lay accumulated flowers, candles and other memorabilia-the core of memorial. Across the memorial, mourners and visitors (according to some media outlets around 400 of them) in shock observed "intruders" chanting and taking over the public space. Soon everybody was surrounded by journalists, TV reporters and the riot police. The memorial became an arena in which participants, both rioters and mourners, verbally and physically defended their right to voice, albeit different, opinion, emotions and political views.

Riot police intervened to try to restore order after the group confronted Muslim women in the crowds and made Nazi salutes (BBC 2016). Not only were the protesters chanting nationalist and anti-immigrant slogans and songs, they were also destroying the memorial by trampling the accumulated flowers, candles and slogans. "We don't believe in candles and flowers. That is for the dead" said one of the rioters to numerous journalists (National Post, 2016). In already forming collective memory of the bystanders, visitors and present mourners, the "savage" act of de-sacralisation of the memorial was taking place. In this sense, the Bourse Memorial was considered to be a consecrated place whose sacredness was threatened by the outsiders (i.e. non-mourners). When the police hit the protesters with a water cannon and a pepper spray, dispersing them forcefully from the city centre, the memorial became also the place of violent contestation. The Belgian Prime Minister and the City Mayor have strongly condemned this behaviour. Charles Michel, the Belgian prime minister, said: "It is highly inappropriate that protesters have disrupted the peaceful reflection at the Bourse. I strongly condemn these disturbances" (National Post 2016). The mayor of Brussels, Yvan Mayeur had a stronger reaction as he was "appalled [...] that such thugs have come to provoke residents at the site of their memorial" (Guardian 2016b).

Two days after these anti-immigrant protests, a wreath-laying ceremony was held to demonstrate Belgium's unity in the face of extremist violence. Interfaith religious leaders, survivors and victims' families united to pay tribute to the victims in a cathedral service. However, on April, 1 a ceremony was organized at a memorial site for the victims at the Place de la Bourse [14]. By the beginning of April, the memorial was attracting fewer visitors, namely people passing through the city centre and some of the tourists who visited the open-space memorial with an aim "to take pictures of the memorial," "express their sympathy for the victims and wounded" and "write the message of peace and solidarity" (Interview 2016). After the violent contestations on March 27 and with an on-going high-alert security concerns, the memorial was considered 
to be "unsafe."

As discussed in this section of the paper, spontaneity of these grassroots memorials lies in their use as a prompt response to an unexpected tragedy. In line with Savage's work $(2009,297)$, undoubtedly the purpose of these "therapeutic memorials," is to 'heal [the] collective psychological injury' from collective traumatic events creating also a sense of community. This appears to be very true in the immediate aftermath of the event, more precisely in the hours and days after the establishment of the memorial. After the birth of the memorial, the number of visitors has exponentially grown expanding from the community of bereavement to more diverse public, with multiple agendas. Therefore, besides therapeutic purpose which is the most prominent role assigned to spontaneous memorials, other roles are exercised through participation in a joint commemorative ritual. Societal tensions and the pressure for the answers about the causes and consequences of the trauma tend to be higher in the first days and weeks after the event. In this period, the memorial is used as a site of contestation, negotiation and resistance.

\section{Memorabilia at the site: Post-it memory}

Having discussed how spontaneous memorials emerged in an immediate aftermath of the terrorist attack and what meanings various stakeholders attach to the latter, this section addresses the content of memorials: its objects and messages. The findings in this section while relating to all three memorials, focus mainly on materials gathered in the Place de la Bourse.

A large number of memorabilia was placed in all memorials. Among these objects the most numerous were: banners, flags, statues, candles, flowers (firstly fresh then plastic), balloons, stuffed animals and other. In line with the research of Margry and Sanchez $(2007,2)$ one common feature of observed memorials in Brussels was "that citizens do not place memorabilia or offerings at memorial sites solely in memory of the deceased" but as symbols of the faith in better future, looking for answers.

A few meters away from the Bourse memorial, an improvised stand offered pens and paper for visitors to write their messages. Two NGO workers from Romania came up with the idea when they realized that the next rain will wipe out all the chalk messages written on the sidewalks and walls: "We just wanted the families to have a hard copy of the warm messages. We wanted to spread solidarity, and have it written on paper" (Deutsche Welle, 2016). Mourners wrote messages that ranged from expression of anger: "Fuck ISIS" or "Fuck terror," through expressing international solidarity in different foreign languages like "Volem pau" [i.e I want peace] or "Imagine all the people living in the peace" to finally conveying messages of a better future: "Bruxelles est belle" [i.e. Brussels is beautiful], "Viva la vie!" [i.e. Celebrate the life], "Union fait la force" [i.e. Union makes force] or "Make love not war." Analysed chalk graffiti and messages written on the Bourse memory site are presented in Table 1. for illustration purposes.

There are four main thematic clusters emerging from more than 200 analysed messages from the site. Firstly, messages of unity and solidarity with Brussels and Belgium are the most salient meanings of these memorabilia. Often paired with cultural and political symbols of Belgium, these messages appeal to sense of patriotism and unity as an answer to insecurity and instability faced by the mourners. Second cluster of messages is future oriented, evoking frequently the words like "strength" and "survival" while contemporary narrating the hardship of the trauma. Third group of messages is of religious reference. Seen that the terrorist organization ISIS claimed the responsibility for the attacks and that attackers themselves came from the Belgian Muslim community, there were numerous references to Islam. These range from anger and blame, to messages that speak of the perils of attributing the culpability and responsibility to any religion. Interestingly, 


\section{Journal of Terrorism Research}

some of the visitors were erasing hateful messages referred to religious background of the attackers. In addition, Christian symbols were also present in the site and references to "prayer", "redemption", "heaven" and "angels" were often present. Finally, there were messages of anger directed towards the perpetrators and terrorist organization to whom they are allegedly associated (i.e. ISIS). Few messages even evoked the ethnic origin of some of the mourners, while a message referring to Belgian colonial past in Africa was also present (e.g. "Je suis belge et je suis Congo" [I am Belgian and I am Congo]).

\begin{tabular}{|l|l|}
\hline Thematic clusters: & Examples: \\
\hline Unity and solidarity & $\begin{array}{l}\text { "Care and love to Belgium", "Pray for } \\
\text { Belgium", "I am Brussels" }\end{array}$ \\
\hline Future oriented & "We will survive", "Brussels is strong" \\
\hline Religious reference & $\begin{array}{l}\text { "Stay united among Christians. " "Not in } \\
\text { the name of Islam", "Terrorists have no } \\
\text { religion" }\end{array}$ \\
\hline Anger & "Daesh go to hell!", "Fuck ISIS" \\
\hline
\end{tabular}

Table 1. Thematic representation of memorabilia's messages present at the Bourse memorial

Numerous messages were written in a wide swath of foreign languages, which not only reflects multicultural character of Brussels, seen through the mourners' eyes as the capital of Europe and Belgium, but also a collective, solidarity expression of public grief by the community of bereavement and visitors alike. The multicultural character of the capital was also represented with an important number of flags of different communities [15] present in Brussels (e.g. Albanian, Turkish, Moroccan, Romanian) which were exposed on its "altar"-the entrance to the actual building of the Bourse on the top of the main staircase. Displayed flags were expression of unity and solidarity of Brussels residents, regardless of their ethnic origins.

Memorabilia present on the site, speaks in favour of national unity and identity confirmation, which is expressed in several ways: a) Belgian bilingual character was omnipresent, with most of the banners in both French and Dutch, b) national symbols such is the Belgian flag were showcased, c) cultural landmarks and symbols (statues of Atomium, Manneken Pis), as well as d) the most important Belgian delicatessen products ( frittes, waffle, beer and chocolate) also remembered in messages of the visitors (e.g. "Make waffles, not war"). Parading national symbols and appealing to patriotism and national identity symbolises the need for unity that the community of bereavement was expressing while facing terror and its consequences. This was visible not only in the urban centre where spontaneous memorial emerged but also around the entire city, when the day after the attacks, many households started placing Belgian flags on their windows and terraces.

\section{Gradual "return to life": Acceleration of memory works}

So far, this paper focused on the emergence and life of spontaneous memorials and their content in immediate aftermath of the Brussels attacks, providing evidence of numerous memorial purposes assigned to these places of memory by a variety of stakeholders. As argued, both emergence and valour of spontaneous memorials spring out of the vernacular of expressions of memory. Using the example of the Bourse memorial 


\section{Journal of Terrorism Research}

as the central place of this vernacular memory, I have demonstrated how its initiators self-manage the memorial in the first two weeks of its existence. This section of the paper, however discusses gradual "return to life", "to normality" illustrating the final stage of the life cycle of spontaneous memorials starting from the third week until its final end (i.e. removal) or transformation to a more "official" place of memory (i.e. designated memorial).

The ephemeral nature of memorabilia (flowers dry, food rot, trash accumulates) and a high number of visitors call for a daily maintenance of the site. Large quantities of lit candles, burning day and night are also a matter of security concerns (i.e. fire). For all these practical reasons, the first sign of change in all the observed sites was an introduction of a scheduled maintenance. By mid-April, with fewer visitors and increased police and military operations regarding the seizure and prosecution of the presumed terrorists, there seemed to be a dire need that the city resumes "normal" rhythms. A fresh sign of that "return to life" was re-opening of the metro station Maelbeek on April, 25.

Before the re-opening, Maelbeek memorial consisted of a large number of memorabilia dispersed around two main entrances to the Station. The exterior of the station was also turned into a spontaneous memorial as people placed dozens of bouquets outside and wrote messages with chalk on the walls facing the Station. During the first three weeks, a small site on the exterior was cordoned off by fences and security workers. However, once the Station was reopened, the public transportation company (STIB) in charge of the site provided a new tool for expression of grief for Brussels' commuters: a memory wall. These memory walls are made of big white boards (approximately $2 \mathrm{~m}$ per $2 \mathrm{~m}$ but the dimensions vary according to site) with a red heart in the centre. Inside the heart, there are drawings of Brussels' landmarks such are Atomium, Heyzel Stadium, Manneken Pis and other cultural symbols of the city ( e.g. a dinosaur-symbol of Brussels' Natural Science museum, Concert Hall-Ancienne Belgique, Bozar, Matongé, African Museum). With the memory wall, commuters were given a specially designed locus to express their emotions, convey their messages and voice their thoughts about the traumatic events which took place in that place of tragedy.

As was observed in the same time frame, Zaventem Airport and Maelbeek metro memorials both became "managed." At the Zaventem airport, where the first form of memorial emerged the day after the attacks, the initiators were the workers of the airport and their families. The initial memory site was very sober and personal, created to mourn the victims but also as an expression of the relief and gratitude for the survival of many who were present that day at their workplace in the Airport. After a partial reopening of the Zaventem airport on May, 1, the memorial fragmentized into several memory walls dispersed between temporary check-ins and corridors of the building. However, at the Airport the memory walls are slightly different: instead of the heart in the middle of a white panel, there is a round shaped Belgian flag with a "B" letter, [16] standing for "Brussels airport" itself, a victim of tragedy.

While both Maelbeek and Zaventem memorial sites evolved over time, transforming into smaller memorials and specially designed memory walls, the Bourse memorial maintained the same form for 60 days after which it was removed. For comparison, clean-up of the flowers left at the gates of Buckingham Palace began 12 days after the death of Princess Diana. The removal and clean-up of the Place de la Republique in Paris where candles, photographs, hand-written letters, and other memorabilia have accumulated since January 2015 has started in August 2016. In Brussels, residents started lamenting of the smell coming from the memorial after several weeks saying that "it was nice 6 weeks ago, now it just looks sad" (McDonald 2016). On the order of the City Council, memorial was finally dismantled on May, 20. by the Brussels' waste management company and the volunteers of the Archive of Brussels who had the hope of collecting some 


\section{Journal of Terrorism Research}

of the messages and objects of the memorial. At the moment of writing this article (2016), the plans for the establishment of a permanent memorial are not known.

As Fullerton et al. $(2003,9)$ demonstrate in analysing the shift from unprompted to official memory works, "memorialization carries the potential to both cause harm as well as to do good," that is why a special thought must be given to the placement of an eventual memorial, but also to its physical aspect and narratives told. As seen from examples analysed in this paper, Brussels' spontaneous memorials emerging in places of atrocity transformed from an open space memorial to more manageable and "adequate" (social) memory walls after one month ( Maelbeek) and a month and a half ( the Airport). The original purpose of both sites of tragedy (i.e. a metro station and an airport) was established very quickly with re-construction works proceeding almost parallel to the criminal investigation. Therefore, the transformation to a more contained physical locus dedicated to expressions of memory ( i.e. memory walls) has supposedly accelerated the return to normality. Nevertheless, the attention of many commuters and tourists passing through Maelbeek metro station and the Airport, the tragic history of these places of atrocity seems not to cease [17].

Plans for the memory works had however started circulating almost immediately after the traumatic events. In Maelbeek station, which prior to the attacks showcased [18] murals of a Belgian artist Benoît Van Innis, a plan for the reconstruction of the site was announced few weeks after the explosion. Further reconstruction works shall allegedly include a commemorative mural by the same artist who himself confirmed these plans:" I got an offer from STIB and the Region of Brussels, to create a new artwork which will be indirectly a commemorative one" (La Capitale.be 2016). For purpose of illustration, one year after the Charlie Hebdo attacks, in memory of people killed in January and November 2015 a plaque and a memorial oak tree were unveiled in Paris (Guardian 2016). As a new research on memory of the Paris attacks shows, the anniversary of the Charlie Hebdo tragedy was chosen to mark this passage to official memorialization (Hollis-Touré 2016).

\section{Concluding remarks}

In a permanent evolution, memory resides on a cross-road of remembering and forgetting, both eternal and ephemeral. Therefore, in every society emerging from a traumatic past there are both, urges "to remember" and efforts to suppress memory in an effort to "move on" or "put the past behind us."

The analysis of a "bottom-up" memorialization of the terrorist attacks in Brussels, speaks in favour of a societal need to remember the present and cope with the trauma. The community of bereavement, consisting of individuals and groups who create spontaneous memorials out of "need to remember" and "seek answers," use these places of memory to start the healing process. In this sense, these places of memory-contrary to Nora's claim that there is no spontaneous memory (1989)-are indeed also "the sites of mourning" (Winter,1995). In stark contrast with the current trend to accelerate memory works by creating plans and projects for "official" memorials immediately after the tragic events, these ephemeral memorials carry a genuine societal response to the tragedy which should be taken into account during eventual creation of a more permanent representations of memory.

As spatial loci and discursive arenas for expression and negotiation of emotions, narratives and identities, spontaneous memorials transcend their own community of bereavement generating transnational solidarity through expression of grief. More research is needed to better understand how European society will embrace memories of terrorism in their collective memory. In that light, dealing with the memories of terrorism, spontaneous memorials and solidarity through memorialization call for fresh theorizing. 


\section{References}

Alexander, Jeffrey C. 2004. “Toward a Theory of Cultural Trauma." In Cultural trauma and collective identity, edited by Alexander, Jeffrey C.; Eyerman, Ron ; Giesen, Bernhard ; Smelser, Neil J. ; Sztompka, Piotr, 1-30. Berkley: University of California Press.

Arendt, Hannah. 1951. The origins of totalitarianism. New York: Harcourt, Brace and Co.

Anderson, Benedict. 1983. Imagined Communities: Reflections on the Origin and Spread of Nationalism. London: Verso.

Assmann, Aleida. 2008. “Transformations between History and Memory." Social Research 75(1): 49-72.

BBC. 2016. “Brussels attacks: Police move against 'hooligan' protesters." March 27.

Bloxham, Donald. 2005. Genocide on trial: war crimes trial and the formation of Holocaust history and memory. Oxford: Oxford university press.

Britton, Dee. 2007. “Arlington's Cairn: Constructing the Commemorative Foundation for United States' Terrorist Victims." Journal of Political and Military Sociology 35(1):17-37.

Butler, Judith. 2009. Frames of war: When is life grievable? London: Verso Press.

Connerton, Paul. 1989. How societies remember. Cambridge: Cambridge University press.

Connerton, Paul. 2012. The spirit of mourning: history, memory and the body. Cambridge: Cambridge University Press.

Dailymail. 2016. "World landmarks were lit up in Belgian colours to honour Brussels victims - so WHY not in London? (Where even Star Wars merited an illuminated Nelson's Column)” March 23.

Dayan, Daniel (ed.) 2006. La terreur spectacle : terrorisme et télévision. Bruxelles : De Boeck.

Deutsche Welle. 2016. “On Place de la Bourse, many nations mourn Brussels dead.” March 27.

De Young, Mary. 1998. “Collective Trauma: Insights from a Research Errand." The American Academy of Experts in Traumatic Stress. Source: http:/ /www.aaets.org/arts/art55.htm, Last access: 14/08/2016.

Donofrio, Theresa Ann. 2010. "Ground Zero and Place-Making Authority: The Conservative Metaphors in 9/11 Families' “Take Back the Memorial” Rhetoric." Western Journal of Communication 74(2):150-169.

Doss, Erika. 2008. “Memorial Mania: Fear, Anxiety, and Public Culture.” Museum 36-43, 72-75.

EU Observer. 2016. “Brussels attack hits all of Europe, EU leaders say." March, 22.

Foley, Malcolm and Lennon, John. 1996. "Editorial: Heart of darkness.” Journal of International Heritage Studies 2(4):195-197.

Foot, Kirsten; Warnick, Barbara; Schneider, Steven M. 2006. "Web-based Memorializing After September 11: Toward a Conceptual Framework." Journal of Computer Mediated Communication 11(1):72-96. 


\section{Journal of Terrorism Research}

Friedland, Nehemia and Merari, Ariel. 1985. “The Psychological Impact of Terrorism: A Double-Edged Sword." Political Psychology 6(4):591-604.

Fullerton Carol S., Ursano, Robert J., Norwood Ann E. and Holloway, Harry H. 2003. “Trauma, Terrorism and Disaster." In_Terrorism and Disaster: Individual and Community Mental Health Interventions, edited by Ursano, Robert J., Fullerton Carol S., Norwood, Ann E., 1-23. Cambridge: Cambridge University Press.

Ginges, Jeremy and Atran, Scott. 2009. "What Motivates Participation in Violent Political Action. Selective Incentives or Parochial Altruism?" Annals of the New York Academy of Sciences 11671(1):115-123.

Granek, Leeat. 2014. "Mourning Sickness: The Politicizations of Grief." Review of General Psychology 18(2):61-68.

Habermas, Jürgen. 2012. The crisis of the European Union: a response. Cambridge : Polity.

Halbwachs, Maurice. 1925. Les cadres sociaux de la mémoire. Paris: Librairie Félix Alcan.

Hobfoll, Stevan E.; Canetti-Nisim, Daphna; Johnson, Robert J. 2006. "Exposure to terrorism, stress-related mental health symptoms, and defensive coping among Jews and Arabs in Israel." Journal of Consulting and Clinical Psychology 74(2): 207-218.

Hollis-Touré, Isabel. 2016. “The multidirectional memory of Charlie Hebdo." French Cultural Studies 27(3):293-302.

Jaspers, Karl. 1961. The question of German guilt. New York : Capricorn books.

Joralemon, Donald. 2015. “Ordering chaos: the process of remembering mass murder." Mortality 20(2) :178191.

La Capitale.be. 2016. "Benoît Van Innis réalisera une nouvelle fresque pour la station de métro Maelbeek, avec une référence au drame du 22 mars.” April, 5.

Levi, Primo. 1958. Se questo è un uomo. Torino: Einaudi.

Low, Setha M. 2004. “The memorialization of September 11: Dominant and local discourses on the rebuilding of the World Trade Center site." American Ethnologist 31(3): 326-339.

Margry, Peter Jan and Sánchez-Carretero, Cristina. 2007. "Memorializing traumatic death." Anthropology Today 23(3):1-2.

Margry, Peter Jan and Sánchez-Carretero, Cristina (eds). 2011. Grassroots Memorials: The Politics of Memorializing Traumatic Death. New York and Oxford: Berghahn.

McDonald, Karl. 2016. "Brussels memorial flowers being left to rot." May, 13. Source: https://inews.co.uk/ essentials/news/world/brussels-flowers-left-wilt-bombing-victims-memorial/Last access: 04/10/2016.

Misztal, Barbara A. 2003. Theories of social remembering. Maidenhead: Open university press.

Moodley, Roy and Costa, Iara. 2006. "Teddy bears, flowers and crucifixes: Collective responses to trauma." International Journal of Health Promotion and Education 44(1):38-42.

National Post. 2016. "'We don't believe in candles and flowers': Neo-Nazis bring violence to peace vigil in Brussels." March 28.

New York Post. 2016. “Woman in hijab rips up Israeli flag at Brussels memorial.” March 24.

Nora, Pierre. 1989. Between Memory and History: Les Lieux de Mémoire, Representations (26):7-25. 


\section{Journal of Terrorism Research}

Pivnick, Billie A. 2011. “Enacting Remembrance: Turning Toward Memorializing September 11th.” Journal of Religion and Health 50(3):499-515.

Portarti, David. (ed.). 2003. September 11th families for peaceful tomorrows: Turning our grief into action for peace. New York, NY: RDV Books.

Ryan, Gery W. and Bernard, H. Russell. 2003. “Techniques to identify themes.” Field Methods (15):85-109.

Renzi, Matteo. 2016. "To fight terrorism we need social workers as much as soldiers." in The Guardian. March, 22.

Santino, Jack. 2003. "Performative Commemoratives, the Personal, and the Public: Spontaneous Shrines, Emergent Ritual, and the Field of Folklore (AFS Presidential Plenary Address)." Journal of American Folklore 117(466):363-372.

Santino, Jack. 2006. Spontaneous shrines and the public memorialization of death. New York: Palgrave Macmillan

Savage, Kirk. 2009. Monument wars: Washington, D.C., the National Mall and the transformation of the memorial landscape. Berkeley, CA: University of California.

Seery, Mark D. ; Silver, Roxane Cohen ; Holman, E. Alison ; Ence, Whitney A.; Chu, Thai Q. 2008.

"Expressing Thoughts and Feelings Following a Collective Trauma: Immediate Responses to 9/11 Predict

Negative Outcomes in a National Sample." Journal of Consulting and Clinical Psychology 76(4):657-667.

Simpson, Edward and Corbridge, Stuart. 2006. "The Geography of Things That May Become Memories: The 2001 Earthquake in Kachchh-Gujarat and the Politics of Rehabilitation in the Prememorial Era." Annals of the Association of American Geographers 96(3):566-585.

Svendsen, Erika S. and Campbell, Lindsay K. 2005. "Living Memorials Project: Year 1 Social and Site Assessment.” United States Department of Agriculture, Forest Service: Delaware.

The Guardian. 2016a. Witnesses to Brussels suicide attacks. March 22. http://www.theguardian.com/world/ video/2016/mar/22/witnesses-to-brussels-suicide-attacks-i-felt-it-was-the-end-of-the-world-video

The Guardian. 2016b. Water cannon used on anti-immigrant protesters in Brussels. March 27.

The Guardian 2016c, Thousands gather in Paris as Hollande leads tributes to terror attack victims. January 10.

The Guardian. 2016d, Staged picture from Brussels bombings prompts ethics debate. March 25

The Guardian. 2016e. "Europe responds to Brussels attacks with show of solidarity." March 22.

Tota, Anna Lisa. 2004. "Ethnographying Public Memory: The Commemorative Genre for the victims of Terrorism in Italy." Qualitative Research 4(2):131-159.

Tota, Anna Lisa. 2005. “Terrorism and Collective Memories Comparing Bologna, Naples and Madrid 11 March." International Journal of Comparative Sociology 46(1-2): 55-7.

Tota, Anna Lisa. 2013. “How to Transform a 'Place of Violence' into a 'Space of Collective Remembering': Italy and its Traumatic Past." Journal of Terrorism Research 4(1). DOI: http://doi.org/10.15664/jtr.623

Vlaams Radio Koor. 2016. “We're playing for healing, hope and the future.” March 25. Source:http://www. vlaamsradiokoor.be/en/news/detail/were-playing-for-healing-hope-and-the-future/ Last access: 12/08/2016.

Winter, Jay. 1995. Sites of Memory, Sites of Mourning: The Great War in European Cultural History. Cambridge: Cambridge University Press. 


\section{Journal of Terrorism Research}

Zerubavel, Eviatar. 2004. Time Maps: Collective Memory and The Social Shape of The Past. Chicago: University of Chicago Press.

\section{Notes}

[1] The Islamic State of Iraq and Syria (ISIS) claimed responsibility for these attacks in which over 300 people were injured and 32 civilians and 3 perpetrators were killed.

[2] Paris attacks refers to two series of coordinated terrorist attacks: events between 7th and 9th of January 2015 (e.g. Charlie Hebdo mass-shootings, Hostage siege at Hypercacher kosher supermarket in Porte de Vincennes); and the November 2015 Paris attacks (i.e. 11/13) that occurred on November, 13. 2015 in Paris (i.e. mass shooting at a concert in the Bataclan theatre) and the city's northern suburb, Saint-Denis (i.e. three suicide bombers struck outside the Stade de France during a football match).

[3] Madrid bombing (i.e 11-M) were bombings against the Cercanías commuter train system of Madrid (Spain) on March, 11. 2004. The attack claimed a total of 192 lives while around 2,000 people were injured.

[4] London bombings (i.e 7/7) - On July, 7. 2005, terrorists detonated three bombs in the London Underground and a fourth on a double-decker bus in the city. Fifty-two people were killed and 700 more were injured.

[5] Utoya massacre is refereeing to two terrorist attacks of Anders Behring Breivik on July, 22. 2011 in Norway: a car bomb explosion in down-town Oslo and a mass-shooting of civilians at the youth summer camp on Utøya island. The attacks claimed a total of 77 lives.

[6] Nice attack happened on July, 14. 2016, when a cargo truck was deliberately driven into crowds on the Promenade des Anglais, in the city of Nice, France. The attack claimed 85 lives while more than 300 people were injured.

[7] Orlando nightclub shootings refers to the mass killing in a gay nightclub in Orlando, United States where 49 people were killed and 53 other wounded.

[8] Take Back Memorial (TBM). See more Donofrio (2010).

[9] Granek (2014,65), shows that "in the United States, the 9/11 memorials tended to commemorate a certain type of citizen, leaving out countless others. For example, those who were illegal immigrants or those who were not United States citizens received little coverage, little public grief, and very little attention in general."

[10[The Bourse plaza is situated in the city centre and was recently turned to a pedestrian zone.

[11] Many of these spontaneous memorials were erected in front of the Belgian embassies around the world.

[12] These two sites were hard to reach in immediate aftermath of the attacks due to the work of first responders, medics, military and police who coordinated the extraction of the victims.

[13] Fox news camera caught on video a young photojournalist "moving the arm of a young girl and directing her in front of the makeshift memorial, while he snaps away with his camera" sparking a debate among internationally renowned news photographers about how often news photographs are staged (Guardian 2016d).

[14] by the Belgian Muslim Executive organization.

[15] Only few EU flags were displayed by the mourners. 


\section{Journal of Terrorism Research}

[16] The same hashtag is promoted by both Maelbeek and Zaventem memory walls: \#BrusselsTribute. Their reference to social media makes of them a sort of Social memory wall.

[17] For example, many journalists reporting from Brussels went on a macabre metro ride, passing through the station Maalbeek after re-opening, interviewing the commuters on 'the sentiment' they prove when driving through the place of explosion and mass death.

[18] Partially damaged in the explosion in March 2016.

\section{About the author}

Ana Milošević is a joint PhD candidate with the University of Leuven in Belgium and the University of Maastricht in the Netherlands. Her research interests cover collective memories, identities and European integration of the post-conflict societies with a special focus on coming to terms with the past. Currently, she is collaborating with the European Observatory on memories, at University of Barcelona in Spain on topics related to transnational memory activism and the politics of memory in the Western Balkans. 